\title{
CODE OF ETHICS FOR PROFESSIONALS OF INFORMATION SYSTEMS - CEPIS MODEL
}

\author{
Helena Dulce Campos \\ Departament of Information Systems, Universidade do Minho, Campus de Azurém 4800-058 Guimarães, Portugal \\ Luis Amaral \\ Departament of Information Systems, Universidade do Minho, Campus de Azurém 4800-058 Guimarães, Portugal
}

\begin{abstract}
Keywords: Information systems, codes of ethics, professional societies, professional competences, professional ethics.
Abstract: On the area of Information Systems Technology (IST) there is a multiplicity of competences and knowledge. In order the professionals may carry them out with success and great advantage, the existence of a structured and standardized framework that could be used as a reference for any organization, is needed. Parallel to this problematic there still exists the acknowledgement of the impossibility of a technological life without ethics. So, a Code of Ethics for Professionals of Information Systems - CEPIS it will be proposed.
\end{abstract}

\section{INTRODUCTION}

Looking to the Portuguese situation related to professions, competences and code of ethics of the IST professionals, we could conclude that there does not exist such a standard. Therefore, the objective of this work is to develop a model - CEPIS - Code of Ethics for Professionals of Information Systems that standardises the ethical behaviour of IST professionals adapted to the portuguese situation. In order to achieve this objective, we propose: (1) a pattern of organizational and operational competences and respective professional skills; (2) the principles and obligations of the professionals for each competence; (3) a code of ethics for each of the identified competences - Organizational and Operational - and Professional Skills.

\section{RELATED WORK}

Ethical questions have been worrying human kind since humans' beings began to live together because ordered, peaceful and productive communities are not possible without guide rules to know how, when and what one should or should not do.

As time went by, communities spread largely, their rules became codes of behaviour in order to ensure everyone knew about their rights and duties and punishments were established when community's ethical rules were violated. When professionals formed their own communities, they developed codes of behaviour which were needed for the well-being of their members and others, namely, with the Hippocratic Oath in the medical community. In the outset, the Information Systems (IS), unlike Law and Medicine, were not a controlled profession (Davison, 2000). Later, professional associations recognized the need of establish standards of ethical behaviour for their own protection as well as for the protection of those they serve.

Computer-related legislation started in the late 1970s. However, the need for ethical behaviour among computer professionals was already recognized by the late 1960 s as the use of computers quickly spread in academic and business organizations. Because computer laws did not exist, professional organizations initiated their own ethical codes (OZ, 1992).

Historically, professional associations viewed code of ethics as mechanisms to establish their status as a profession or as a means to regulate their membership and thereby convince the public that they deserve to be self-regulating. Codes of ethics have tended to list possible violations and threaten sanctions for such violations (Gotterbarn et al, 1998).

The Association for Computing Machinery (ACM) was pioneer of the first code, the Code of Professional Conduct, was adopted in 1972. The 
latest ACM code, the Code of Ethics and Professional Conduct was adopted in 1992 and takes a new direction (Anderson et al, 1993). Others organizations like Australian Computer Society (ACS), American Society for Information Systems (ASIS), Association of Information Technology Professionals (AITP), British Computer Society (BCS), Canadian Information Processing Society (CIPS), Computer Society of India (CSI), Computer Society of South Africa (CSSA), Data Processing Management Association (DPMA), Hong Kong Computer Society (HKCS), Institute for Certification of Computer Professionals (ICCP), Institute of Electrical and Electronics Engineers (IEEE), Institute for Management of Information System IMIS, Singapore Computer Society (SCS), and Software Engineering Ethics and Professional Practices (SEEPE), have their own code of ethics.

At Portugal exists an Information Systems Association but does not exist a code.

\section{CODE OF ETHICS FOR PROFESSIONALS OF INFORMATION SYSTEMS - CEPIS}

A professional code of ethics must address specific high-risk activities within the scope of daily operations of the professionals' work or activities (Ferrel, 1999). A profession's code of ethics is perhaps its most visible and explicit enunciation of its professional norms (Frankel, 1989).

It is essential maintain high levels of professional competence by continually upgrading of the skills and knowledge, to maximise the potential for lifetime employability.

In order to reach our goal, as referred above, the model will comprises three components that will be detailed below.

\subsection{A Pattern of Organizational and Operational Competences and Respective Professional Skills}

A pattern of organizational and operational competences and respective professional skills is defined as a tridimensional matrix. The matrix identifies and classifies a pattern of competences organizational and operational - and respective skills and levels of professional responsibilities adjusting to the respective importance, that the IST have in the organizations, and always aiming at the technological and methodological evolutions is proposed. See table 1 and, figure 1 and 2 as an example of an extract of the proposed matrix.

Table 1: Extract of the one competences pattern matrix (Adapted from "BCS Skills Manager").

\begin{tabular}{|c|c|c|}
\hline $\begin{array}{l}\text { Organizational } \\
\text { Competences } \\
\text { (ORGC) }\end{array}$ & $\begin{array}{l}\text { Operational } \\
\text { Competences } \\
\text { (OPC) }\end{array}$ & $\begin{array}{c}\text { Professional } \\
\text { Skills }\end{array}$ \\
\hline \multirow{17}{*}{$\begin{array}{l}\text { Development } \\
\& \\
\text { Implementation }\end{array}$} & \multirow[t]{11}{*}{ Systems Development } & Business Analysis \\
\hline & & Data Analysis \\
\hline & & Technical Authority \\
\hline & & Systems Design \\
\hline & & Network Design \\
\hline & & Database Design \\
\hline & & Programming / Software Development \\
\hline & & Safety Engineering \\
\hline & & Software Engineering \\
\hline & & Web Site Specialism \\
\hline & & Systems Testing \\
\hline & \multirow[t]{2}{*}{ Human Factors } & Systems Ergonomics \\
\hline & & Media Creation \\
\hline & \multirow[t]{4}{*}{ Installation \& Integration } & Systems Integration \\
\hline & & Software Integration \\
\hline & & Systems Installation/decommissioning \\
\hline & & Installation \& Implementation \\
\hline
\end{tabular}




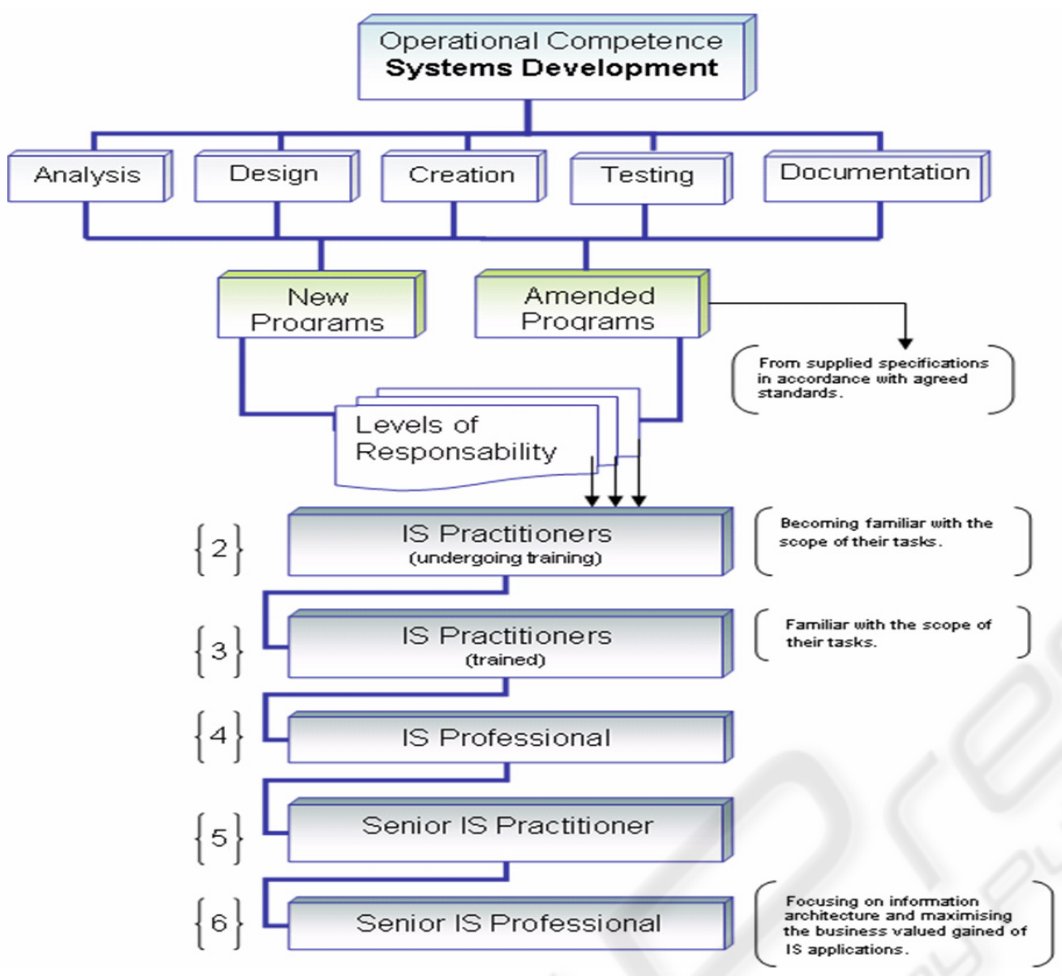

Figure 1: Operational Competence - Systems Development.

\subsection{Principles and Obligations of the Professionals for Each Competence}

Identified the main competences and skills of the IST professionals, it also have to be identified the fundamental ethical principals, in order to achieve their better performance. In a first analyse, these principals will include generic moral imperatives, more specific professional responsibilities in the performance of the profession, imperatives of organizational leadership and the biggest conformity possible.

As a result of this work, it must be achieved a proposal for a code of ethics consisting of two parts:

The principle fundamental ethics, immutable in time and place, that is found above all philosophical and political concept and who are equal in any profession.

On the performing of each profession the principle specific ethics can vary in time and place.

\subsection{A Code of Ethics for Each of the Identified Competences}

In order to observe if there exists the concern and practice of ethical professional attitudes at an academic and organizational level, a fieldwork will be developed.

For us, the term professionals not only include academicals, professionals, researchers, executives and consulters but also students of the IST area (who will be the professionals of the near future) (Couger, 1989). So the fieldwork will be split into two great sides: the academic and the organizational.

On the academic side, the work to be developed consists of an analysis of how a course in particular (Degree or MBA) prevents on their curriculum an ethical formation of their students. Namely, if there exists ethical disciplines that identify aspects that leads to ethical behaviours and preoccupations; that prepares them to deal with ethical questions; that alerts them for what kind of ethical behaviour is acceptable or not and that encourage them for better practices.

On the organizational side, to give an answer to one of the key problems referred on the development of the code (the fact that the validation of the individuals who were going to be influenced by the code completely is apart), we proceed with the fieldwork that will consist on the application of the proposed CEPIS model, in the different organizations and areas and that possesses a IST department, hoping to obtain as a final result the validation and the contribution of the model in the enrichment and improvement of the performance of the professionals in the IST communities. The great 
finality would be that the own IST professionals will test the proposed model in order to be validated empirically.

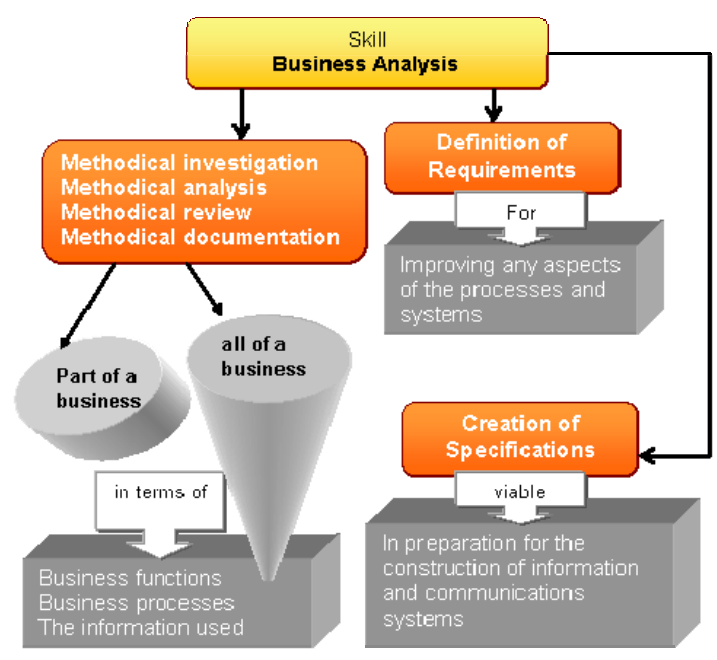

Figure 2: Professional skills - Business Analysis.

On the application of the code it is necessary to have in mind the own requirements of each organisation, the respective individual competences attributed to their professionals; their culture; their mission; their tradition; their strategic vision; their history; their dimension; their image and their market, i.e. the context were it is inserted. So, possibly there will be found surprises and even interesting establishments.

\section{SUMMARY}

To summarize a Code of Ethics for Professionals of Information Systems - CEPIS model - has been outlined. It is hoped that, once developed, this model will represent a practical contribution to de existence of a Code of Ethics that could be applied to the Portuguese professionals.

\section{REFERENCES}

ACM, Association for Computing Machinery ,http://www.acm.org, accessed on 5 October 2005.

ACS, Australian Computer Society, http://www.acs.org.au/, accessed on 17 October 2005.

AITP, Association of Information Technology Professionals, http://www.aitp.org, accessed on 17 October 2005.

Anderson, R., Johnson, D., Gotterbarn, D. ,and Perrolle, J., 1993. Using the New ACM Code of Ethics in Decision Making. Communications of the ACM, Vol.36, No.2, pp. 98-107.
ASIS, American Society for Information Systems, http://www.asis.org, accessed on 17 October 2005.

BCS, British Computer Society, http://www.bcs.org/BCS/AboutBCS/codes, accessed on 17 October 2005.

Berleur, J., Duquenoy, P., Holvast, J., Jones, M., Kimppa, K., Sizer, R. and Whitehouse, D., 2004. Criteria and Procedures for Developing Codes of Ethics or of Conduct, IFIP-SIG9,2.2, IFIP Special Interest Group on a Framework for Ethics of Computing, IFIP Press.

CIPS, Canadian Information Processing Society, http://www.cips.ca/about/, accessed on 17 October 2005.

Couger, J. D., 1989. Preparing IS Students to Deal With Ethical Issues, MIS Quartely, pp. 211-18.

CSI, http://www.csi-india.org, accessed on 17 October 2005.

CSSA, Computer Society of South Africa http://www.cssa.org.za, accessed on 17 October 2005.

Davison, R. M., 2000. Professional Ethics in Information Systems: A Personal Perspective, Dept.of Information Systems, CAIS, April, Vol. 3, article 8.

DPMA, Data Processing Management Association http://courses.cs.vt.edu/ cs3604/lib/WorldCodes/DP MA.Standards.html, accessed on 17 October 2005.

Ferrel, O.C., 1998. An Assessment of the Proposed Academy of Marketing Science Code of Ethics for Marketing Educator, Journal of Business Ethics, 19(2), pp. 225-228.

Frankel, M.S., 1989. Professionals Codes: Why, How, and With What Impact?, Journal of Business Ethics, pp. 109-105.

HKCS, Hong Kong Computer Society http://www.hkcs.org.hk, accessed on 17 October 2005.

ICCP, Institute for Certification of Computer Professionals, http://www.iccp.org, accessed on 17 October 2005.

IEEE, Institute of Electrical and Electronics Engineers, http://www.ieee.org/portal/site, accessed on 17 October 2005.

IMIS, Institute for Management of Information System, http://www.imis.org.uk/, accessed on 17 October 2005.

OZ, E., 1992. Ethical Standards for Information Systems Professionals: A Case for a Unified Code. MIS Quartely, pp. 423-433.

SCS, Singapore Computer Society, http://www.scs.org.sg/, accessed on 17 October 2005.

SEEPE, Software Engineering Ethics and Professional Practices - This Code was developed by the IEEE$\mathrm{CS} / \mathrm{ACM}$ joint task force http://csciwww.etsu.edu/gotterbarn/SECEPP, accessed on 17 October 2005. 